ZDZISŁAW GOGOLA OFMCONV.

\title{
PARIACOTO - MISJA BRACI MNIEJSZYCH KONWENTUALNYCH
}

\author{
FR A N ISZKANIE W PERU
}

Pierwsze ślady obecności franciszkanów w Peru pochodzą sprzed 450-ciu lat. O. Marcos de Niza przybył na te ziemie wraz z ekspedycją Francisca Pizarra. Według kronik w roku 1532 wraz z dwunastoma współbraćmi rozpoczął pracę misyjną wśród tutejszej ludności. Francuski podróżnik Artur Thouar pisał o postawie franciszkanów działających w misjach na terenie Ameryki Południowej: „Franciszkanie wiedzeni uczuciem żywej wiary zaszczepili krzyż Chrystusowy w tych dzikich okolicach narażając się na mnogie niebezpieczeństwa. Sami jedni zebrali 10 tysięcy Indian i osadzili ich we wsiach, które sami zbudowali”'. W wieku XVI klasztory franciszkańskie istniały już w wielu miejscowościach promieniując swą działalnością na znacznym terenie i notując duże liczby nawróceń.

To odległe tonące $w$ mrokach historii dzieje. Zmienił się świat, metody ewangelizacji, podejście do misji w odmiennych kulturowo narodach. Publikacja przedstawia dzieje jednej $\mathrm{z}$ wielu misji prowadzonych przez Krakowska Prowincje Św. Antoniego i Błogosławionego Jakuba Strzemię w Ameryce Południowej. Powstała w roku 1989 i działa do dziś. Jej siedzibą jest położona na wys. około 1300 m n.p.m. w Andach mała wioska Pariacoto.

Dlaczego nieznane dotychczas położone w górach Pariacoto stało się miejscem pielgrzymek, symbolem pojednania, pokoju i dobra? Historię misji nakreślono na szerszym tle, aby lepiej wyjaśnić wydarzenia, które zaszły tam w ostatnim czasie.

\section{KRAINA KONTRASTÓW}

Peru leży na półkuli południowej, między zerowym i $18^{\circ}$ szerokości geograficznej południowej i $69^{\circ}-81^{\circ}$ długości geograficznej zachodniej. Rozciaga się od Amazonki, przez Andy do wybrzeża Oceanu Spokojnego - to

${ }^{1} \mathrm{~J}$. Ho l u b ow i c z, Działalność misyjna zakonów św. Franciszka, Kraków 1886, s. 134 i ns. 
dlatego w tym jednym państwie można w stosunkowo krótkim czasie przemieścić się w trzy zupelnie róż̇ie od siebie regiony geograficzne. Peru leży w strefie klimatu równikowego i zwrotnikowego, ale na panujące tam warunki atmosferyczne ogromny wpływ ma wysokość nad poziom morza - wysokie pasma Andów - oraz wpływ Oceanu Spokojnego, a szczególnie zimnego Prądu Peruwiańskiego. Pas nabrzeżny ciągnący się wzdłuż Oceanu Spokojnego pustynny i stepowy, nazywa się Costa. Średnia temperatura notowana jest na tym obszarze od $16-20^{\circ} \mathrm{C}$.

Sierra to teren andyjski. Andy to najmłodsze góry świata, to jakby świeża blizna na globie ziemskim. Pod nimi ciągle coś się dzieje, o czym przypominają wybuchy wulkanów i wstrząsy sejsmiczne, szczególnie u wybrzeży Pacyfiku. Średnia wysokość szczytów wynosi około czterech tysięcy m. n.p.m. Selva natomiast to wschodnie równiny przedgórskie z Amazonią.

W Peru można wyróżnić dwie pory klimatyczne: wilgotną i suchą. Wybrzeże i zachodnie rejony Andów są położone w strefie suchej. Podczas lata (okres od października do kwietnia) niebo jest tam bezchmurne i panują upały. $\mathrm{W}$ pozostałej części roku jest mglisto i słońce pokazuje się bardzo rzadko. W centralnym rejonie kraju oraz we wschodniej części Andów, ubogi w opady atmosferyczne okres trwa od maja do września.

W niższych partiach Andów, nadających się do rolniczego wykorzystania, problem stanowi erozja gleb. Najlepsze gleby można właściwie spotkać tylko w dolinach rzek².

Peru graniczy z Boliwia, Chile, Brazylia, Kolumbią i Ekwadorem oraz Oceanem Spokojnym. Ma powierzchnię $1285216 \mathrm{~km}^{2}$ i ponad 24,4 miliony ludności (70,1\% miejska, 29,9\% wiejska). To daje dość niską gęstość zaludnienia, bo tylko 18 osób na kilometr kwadratowy.

Stolica państwa jest Lima, a oficjalnym językiem jest język hiszpański, drugi oficjalny to język quechua. Kolebką quechua lub quichua było południowe Peru. Językiem aymara posługiwało się szczególnie plemię Indian Collas, zamieszkujących okolice jeziora Titicaca. Peru podzielone jest na 24 departamenty i jedną prowincję konstytucyjną. Jednostką monetarnąjest sol ${ }^{3}$.

\section{PERU DAWNE I WSPÓŁCZESNE}

Współczesne Peru trudno byłoby zrozumieć bez znajomości historii Inków. Dzisiejsi Indianie w Peru, Ekwadorze, Boliwii i południowo-zachodniej Argentynie są w znacznej mierze potomkami ludności zamieszkującej dawne

${ }^{2}$ Wielka Encyklopedia Powszechna, t. 8, Warszawa 1966, s. 586-587.

3 J. S zt o l cman, Czwarty Polak za Kordylierami, Warszawa 1982, s. 90 i ns; A. K r zanowski, Prahistoria andyjskiej doliny. Studium przedhiszpańskiego osadnictwa w dorzeczu Alto Chicamy w pótnocnych Andach, Peru, Wrocław-Warszawa-Kraków-GdańskŁódź 1984, passim. 
państwo Inków ${ }^{4}$. Odziedziczyli oni nie tylko rysy twarzy, kolor skóry, budowę ciała, ale i specyficzną mentalność, kulturę i zwyczaje.

Inkowie to środkowoandyjski lud indiański. Słońcu oddawali cześć jako ojcu swemu i bogu - pisał Christóbal de Molina w dziele pt. Ritos y Fábulas de los Incas ${ }^{5}$.

Według starej legendy, ludzie żyli bez praw i religii. Inti, litując się nad nimi, zesłał na Ziemię swoje dzieci, byli to Manco Capac i Mama Ocllo i nakazał im uczyć lud prawdziwego, godnego życia ${ }^{6}$. Podobno pojawili się w pobliżu jeziora Titicaca i wyruszyli na północ ${ }^{7}$. Około roku 1200 Inka zjednoczył wszystkie tereny pod swoją władza, dał początek panującej dynastii i założył państwo obejmujące ogromny obszar. Było to dzisiejsze Peru, Ekwador, Boliwia, północne Chile i część Argentyny.

Stolicą państwa było Cuzco leżące w obecnym Peru. Kiedy wkroczyli do niego Europejczycy, zadziwił ich plan, według którego było ono zbudowane: zabudowania ułożone były w kształt pumy ${ }^{8}$. Używano języka keczua ${ }^{9}$. Państwo było silne i gęsto jak na ówczesne czasy zaludnione. Liczyło około 7 milionów mieszkańców.

Na czele imperium stał syn Słońca - Sapa Inka, uważany za boskiego namiestnika boga na ziemi. Był on władcą najwyższym. Ciekawe, że tak jak w Egipcie, na tym odległym od Afryki kontynencie żoną wodza była jego siostra. Chodziło o to, by zachować czystość krwi, by w żyłach kolejnego władcy płynęła również tylko boska krew ${ }^{10}$.

Gdy w październiku 1492 roku Kolumb odkrył Nowy Świat, oznaczało to również zwrot w historii inkaskiego Peru. Od roku 1532 rozpoczą się systematyczny podbój dzisiejszego Peru przez Hiszpanów. W rok później zdobyli stolice imperium Inków Cuzco. Po obaleniu władcy Inków Atahualpy, państwo inkaskie przestało istnieć. W roku 1535 Hiszpanie na wybrzeżu założyli wkrótce miasto Limę, które ustanowili stolica nowej części Hiszpanii. Od 1542 do 1821 roku miała ona status hiszpańskiego wicekrólestwa Peru. Dzi-

${ }^{4}$ In ca Garcilaso de la Vega, O Inkach uwagi prawdziwe, Warszawa 2000, passim.

${ }^{5}$ C. D e Molin a, [w:] S. H u b e r, Państwo Inków, Warszawa 1968, s. 75.

${ }^{6} \mathrm{~S}$. H u b e r, Państwo Inków, Warszawa 1968, s. 76-77.

${ }^{7}$ E. L i p s, Ksiega Indian, Warszawa 1960, s. 394-395.

${ }^{8}$ J. Salcamaygua, J. De Santa Cruz Pachacuti Yamqui Salcam a y g u a, Opowieść o starożytnościach Królestwa Peru, [w:] Dzieje Inków przez nich samych opisane. Kroniki Peruwiańskie, pod red. J. Szemińskiego, Warszawa 1989, s. 77-78.

${ }^{9}$ Keczua, Quechua, to grupa plemion indiańskich tworząca odrębną rodzinę językową język keczua. Zamieszkuje obszary Andów w Peru, Ekwadorze, Boliwii. Stanowią największa i najbardziej zwartą grupe plemion indiańskich w Ameryce Południowej. W XV w. zostali podbici przez Inków. Nazwę Quechua wprowadzili misjonarze hiszpańscy, początkowo określając w ten sposób język, jakim posługiwali się Indianie, a później również plemiona indiańskie. Misjonarze uczynili keczua jednym z języków chrystianizacji Indian i rozprzestrzenili go wśród wielu plemion. W 1975 r. w Peru keczua został uznany jako język urzędowy obok hiszpańskiego. - A. De m bi cz, J. Makowski, A. Malinow sk i, M. Skoc z ek, Stownik terminów geograficznych Ameryki Lacińskiej, Warszawa 1979, s. 189-190.

${ }^{10}$ A. M ét r a u x, Inkowie, Warszawa 1968, s. 201. 
kie, wydawałoby się, Andy były jednak środowiskiem sprzyjającym kolonizatırom. W chłodnym klimacie można było uprawiać pszenicę i jęczmień, a sprowadzane przez Hiszpanów bydło i owce także czuły się dobrze na andyjskich łakach. Natomiast obszary położone nisko miały charakter bagienny lub pustynny i były bardzo trudne do zagospodarowania.

Król nadawał Hiszpanom przywileje m.in. w postaci encomiendas, tj. przydziałów ziemi wraz $z$ Indianami ${ }^{11}$. Trudno jest zliczyć powstania Indian. Wszystkie okrutnie thumiono. Hiszpańska korona umacniała swą potęge przez zabór kolejnych ziem, z których rabowano szlachetne kamienie, miedź, żelazo, złoto. To właśnie złoto głównie interesowało konkwistadorów. Nie zwracali oni uwagi na pozostałości wspaniałych dawnych kultur.

Dopiero w roku 1821, po wkroczeniu armii San Martina, ogłoszono niepodległość Peru. W roku 1822 zwołano kongres. Były to jednak jedynie pozory stabilizacji. W 1825 roku oderwało się tzw. Górne Peru, tworząc państwo Boliwię. Permanentny stan chaosu politycznego nieuchronnie prowadził do gospodarczego upadku. Ponowny kryzys nastapił po wojnie z Hiszpanią w latach $1866-1871^{12}$. Peru po uzyskaniu niepodległości nie było spokojne. Podczas pół wieku trwającej niepodległości zanotowano aż 40 rewolucji. Mało który z prezydentów umarł śmiercią naturalną. Szczególnie dotkliwa była wojna, którą w 1879 roku Chile rozpoczęło z Boliwią i Peru o złoża saletry. Była to tzw. Wojna Pacyfiku, na skutek której Lima przez cztery lata (1881-1884) znajdowała się w rękach Chilijczyków.

Otwarcie Kanału Panamskiego ożywiło handel i rozwój przemysłu. Peru ciągle było atrakcyjnym terenem, dlatego po I wojnie światowej USA zaczęły tam umacniać swoje wpływy. Lata dwudzieste to znowu strajki, powstania chłopskie, walki i marzenia o prawdziwej niepodległości. Naród wykrwawiały również niekończące się spory o tereny przygraniczne, głównie z Kolumbią i Ekwadorem. W 1930 roku powstała Peruwiańska Partia Komunistyczna.

Czasy współczesne również obfitują w poważne trudności gospodarcze. Sa one wynikiem zadłużenia, inflacji i bezrobocia. Wszystko to stworzyło doskonały grunt do narodzin terroryzmu ${ }^{13}$.

${ }^{11}$ H. M. B a i 1 ey, A. P. N a s a ti r, Dzieje Ameryki Łacińskiej, Warszawa 1969, s. 204; Encomienda - była to wielka posiadłość ziemska nadana przez króla hiszpańskiego w koloniach. Encomendero nie był jednak jej faktycznym właścicielem, lecz mial prawo władania ziemią i ludźmi na niej mieszkającymi do swej śmierci lub do chwili kiedy król cofnął swoje nadanie. Indianie mieszkający w obrębie encomiendy mieli własne działki ziemi, ale prócz tego byli zobowiazani pracować określoną ilość czasu na rzecz swego pana, który z kolei miał obowiązek opiekować się nimi i dbać o ich potrzeby. W praktyce encomendero miał bezwzględną władzę w swych włościach, a Indian do nich przypisanych traktował jak niewolników (mimo zee nimi formalnie nie byli). Encomienda, wzorowana na stosunkach panujących w tych czasach w Hiszpanii, została wprowadzona we wszystkich koloniach hiszpańskich bezpośrednio po podboju, a zniesiono ją dopiero w 1720 r. nadając ziemię na własność.

${ }^{12}$ Dzieje Ameryki Eacińskiej od schyłku epoki kolonialnej do czasów współczesnych, pod red. T. Łepkowskiego, Warszawa 1977, s. 85 i ns.

${ }^{13}$ S. B ratk ow ski, Skqd przychodzimy?, Warszawa 1975, s. 124 i ns.; E. D z i k ow s k a, Limańskie $A B C$, Warszawa 1982, s. 104 i ns.; Peru-ludność, [w:] Encyklopedia Powszechna, t. 4, Warszawa 1996, s. 838. 
Wiele napięć w społeczeństwie współczesnego Peru zostało wywołanych panującymi tu stosunkami własnościowymi. Najbardziej obrazowo można to przedstawić na przykładzie własności ziemskiej. Statystyki informują iż zaledwie 40 najbogatszych rodzin w Peru ma w posiadaniu $90 \%$ ziemi uprawnej kraju. Księża katoliccy, którzy stykają się w swej pracy na co dzień z problemami biedoty i skrajnego ubóstwa, równieź zaczęli analizować przyczyny tego stanu rzeczy. Okazało się, że zarówno na nizinach, jak i w górzystych partiach kraju zaledwie $2 \%$ właścicieli posiadało ponad $60 \%$ gruntów uprawnych. Polaryzacja społeczeństwa zwiększała się z roku na rok. Napięcia rosły i pewnie dlatego przeszła przez kraj rewolucja. W roku 1968 na dziedziniec pałacu prezydenckiego w Limie wjechały czołgi. Prezydent Fernando Belaunde Terry uciekł do Paragwaju.

Władzę w kraju przejęła junta wojskowa. Na jej czele stanął 58-letni generał Juan Velasco Alvarado, który wsławił się między innymi tym, że w 1969 roku wydał dekret o reformie rolnej, dzięki której ogromne latyfundia na wybrzeżu i w Andach uległy wywłaszczeniu. Po siedmiu latach rządów, 29 sierpnia 1975 roku, ówczesny premier Francisco Morales Bermudes, już bez strzelaniny i demonstracji czołgów, poinformował generała Alvarado, że zgodnie z wolą wojska przejmuje rządy w Peru ${ }^{14}$.

System polityczny Peru to republika prezydencka. Głowa państwa jest prezydent wybierany na 5 lat w wyborach powszechnych. Władza ustawodawcza należy do jednoizbowego kongresu (120-osobowego), wybieranego również na 5 lat. Władzą wykonawczą jest rząd powoływany przez prezydenta. $\mathrm{Na}$ czele rządu stoi premier.

W wyniku wyborów w 1990 roku prezydentem został polityk pochodzenia japońskiego Alberto Fujimori, agronom z wykształcenia, rektor jednej z uczelni rolniczych. Do swoich priorytetów A. Fujimori zaliczył reformę administracji i sądownictwa, prywatyzację przedsiębiorstw państwowych, zwalczanie monopoli oraz położenie kresu terroryzmowi partyzanckich organizacji lewicowych. Konsekwentne działania rządu w latach 1990-1994 doprowadziły do bardzo poważnego osłabienia działalności Sendero Luminoso i innych tego typu ugrupowań. Przełomowe znaczenie $\mathrm{w}$ walce $\mathrm{z}$ terroryzmem miało aresztowanie w 1992 roku przywódcy Świetlistego Szlaku A. Guzmana i skazanie go na karę dożywotniego więzienia za śmierć ponad 26 tys. osób w okresie minionych dwunastu lat. W kwietniu 1992 roku A. Fujimori rozwiązał parlament oraz tymczasowo zawiesił swobody konstytucyjne. Zapowiedział zmianę konstytucji, modernizację władzy ustawodawczej i sądowniczej oraz energiczną walkę z terrorystami i handlarzami narkotyków.

W 1993 roku Konstytuanta uchwaliła nową konstytucję (dwunastą w historii tego państwa). Główne przyjęte reformy to: ustanowienie jednoizbowego parlamentu w liczbie 120 deputowanych, wybieranego na 5 lat, oraz prawo reelekcji prezydenta na następną 5-letnią kadencję ${ }^{15}$.

\footnotetext{
${ }^{14}$ M. R ó ż y c k i , Peruwiańskie spotkania, Warszawa 1989, s. 109 i ns.

${ }^{15}$ G. P on s M u z z o, Compendio de historia del Perú, Lima 1995, s. 210 i ns.
} 
W czerwcu 2001 roku po raz pierwszy w dziejach Peru prezydentem zostal obywatel pochodzenia indiániskiegó 55-letini Alejandro Toledo ${ }^{16}$.

\section{FRANCISZKAŃSKA MISJA W PARIACOTO}

W 1985 roku Kuria Generalna Zakonu Braci Mniejszych Konwentualnych OFMConv w Rzymie opracowała projekt założenia nowej placówki misyjnej w Ameryce Lacińskiej w Peru. Owym projektem zainteresowana została Prowincja św. Antoniego ze Stanów Zjednoczonych. Rozpoczęto więc konkretnie prace i działania przygotowujące do zatwierdzenia tego projektu przez Definitorium Generalne (Rada Generalna).

Projekt został zatwierdzony w 1986 roku, dotyczył diecezji Chimbote parafii Pariacoto. Biskup diecezji Chimbote został powiadomiony o tym, że pod koniec lutego 1987 roku przybędą franciszkanie z Ameryki Północnej ${ }^{17}$. Pojawiły się jednak trudności obiektywne, które uniemożliwiły rozpoczęcie pracy w Pariacoto. Na spotkaniu FALC-u ${ }^{18}$, które odbyło się w Costa Rica w dniach $31.01-06.02 .1987$ roku $^{19}$, prowincjał prowincji św. Antoniego z USA o. Daniel Pietrzak poinformował o. Generała Lanfranco Serriniego, że nie może zrealizować zobowiązania i wysłać misjonarzy do diecezji Chimbote. W tej sytuacji projekt misji wrócił do Kurii Generalnej, a biskupowi Luisowi Bambarenowi w Chimbote zakomunikowano, że plan przyjęcia misji przez Zakon zostaje przesunięty na późniejszy okres.

Zarząd generalny Zakonu rozpoczął od nowa rozmowy na temat przyjęcia misji w Pariacoto. W 1987 roku w Rzymie asystent generalny o. Miguel López rozmawiał $\mathrm{z}$ asystentem prowincjalnym o. Zdzisławem Gogolą na temat przyjęcia tej misji przez Polską Prowincję św. Antoniego i bł. Jakuba Strzemię. Asystent generalny przekazał cały materiał przygotowany uprzednio dla prowincji USA ${ }^{20}$.

Biskup Bambaren wysłał pismo do prowincjała o. Feliksa Stasicy, w którym wyrażał prośbę o założenie klasztoru franciszkańskiego i przejęcie parafii „Señor de Mayo” w Pariacoto. Zaznaczył, że Kolegium Konsultorów Diecezji odniosło się przychylnie co do zatwierdzenia tej franciszkańskiej misji. Dołączył jeszcze projekt umowy, która miała być zawarta pomiędzy Zakonem Braci Mniejszych Konwentualnych Prowincji św. Antoniego i bł. Jakuba Strzemię z Krakowa a diecezją Chimbote ${ }^{21}$.

${ }^{16}$ Alejandro Toledo, „Paris Match” 21.06.2001, s. 82-85.

${ }^{17}$ Archiwum Kurii Generalnej w Rzymie (dalej AKGR). Teka Pariacoto, Akta luźne.

${ }^{18}$ FALC - Federación de los Hermanos Menores Conventuales de América Latina (Federacja Braci Mniejszych Konwentualnych Ameryki Łacińskiej).

${ }^{19}$ L. S e rrin i OFMConv, Asterischi di Viaggio, Bari 1995, s. 174-175.

${ }^{20}$ Archiwum Kurii Prowincjalnej w Krakowie (dalej AKPK). Teczka Pariacoto, Korespondencja asystenta generalnego o. Miguela Lópeza do prowincjała w Krakowie o. Feliksa Stasicy $1987 \mathrm{r}$.

${ }^{21}$ AKPK. Korespondencja bpa Luisa Bambaréna do prowincjała o. Feliksa Stasicy $\mathrm{z}$ dnia $6.01 .1988 \mathrm{r}$. 
Definitorium prowincjalne przestudiowało projekt przyszłej misji i powstała myśl aby powierzyć o. Peregrynowi Ziobro, który pracował w Boliwii $^{22}$, by ten rozeznał sytuacje w Peru i dał sprawozdanie. Jako wieloletni misjonarz w Boliwii dobrze wywiązał się z powierzonego mu zadania i przesłał sprawozdanie do prowincjała o. Feliksa Stasicy. W sprawozdaniu o. Peregryn opisał stan faktyczny oraz zasugerował, aby przyjąć także zaproszenie kardynała Juana Landázuri, który wyraził pragnienie przyjęcia franciszkanów do Limy ${ }^{23}$.

Na spotkaniu o. generała, asystenta od spraw misji, o. wikariusza prowincji z Krakowa i kustosza prowincjalnego z Boliwii, które odbyło sie w Rzymie, omówiono szczegóły związane z przyjęciem przez prowincję tejże misji. Ustalono także termin wyjazdu misjonarzy na październik 1988 roku. Planowano aby kurs języka hiszpańskiego odbywał się w mieście Trujillo ${ }^{24}$. Rada Prowincjalna na odbytej sesji 30 czerwca 1988 r. powzięła uchwałę o utworzeniu przez prowincje misji w Peru, w diecezji Chimbote w miejscowości Pariacoto. O postanowieniu tym został poinformowany generał zakonu, który listem z dnia 14 września 1988 r. aprobował tę uchwałę Rady Prowincjalnej i wyraził radość z bliskiej już obecności misjonarzy w tym kraju Ameryki Łacińskiej ${ }^{25}$.

Zgodnie z uchwałą Rady Prowincjalnej z dnia 30 czerwca 1988 roku o przyjęciu przez naszą Prowincję misji w Peru, dwaj kandydaci o. Zbigniew Strzałkowski i o. Jarosław Wysoczański, podjęli przygotowania do wyjazdu. Przygotowania te, a zwłaszcza załatwiania starań o otrzymanie wizy wyjazdowej znacznie się przeciaggały. Ostatecznie wszystko zostało załatwione pomyślnie i wymienieni ojcowie mogli opuścić kraj i udać się do Peru. Wyjazd nastapił w dniu 30 listopada 1988 r. drogą lotniczą Aerofłotem z Warszawy via Moskwa do Limy ${ }^{26}$.

Misjonarze szczęśliwie dotarli do Peru i rozpoczęli naukę języka hiszpańskiego, poznawanie kultury i religijności nowego kraju. Biskup Bambarén powiadomił prowincjała o. Stasicę, że misjonarze zostali bardzo życzliwie przyjęci, a fakt ich przybycia został oceniony przez Konferencję Episkopatu Peru jako historyczny. Biskup zorganizował im pobyt, o. Zbigniewa oddelegował do Moro, o. Jarosława pozostawił w Chimbote ${ }^{27}$.

Przez osiem miesięcy pracowali w wyznaczonych miejscach, ucząc się języka, poznając kulturę, zwyczaje, przyglądając się stylowi pracy duszpaster-

${ }^{22}$ O. Peregryn Ziobro pracuje w Montero. Przybył tam wraz z trzema franciszkanami w $1977 \mathrm{r}$.

${ }^{23}$ AKPK. Korespondencja o. Peregryna Ziobro z Montero do prowincjała o. Feliksa Stasicy w Krakowie z dnia 9.04.1988 r.

${ }^{24}$ AKPK. Korespondencja generała zakonu o. Lanfranco Serriniego do prowincjała o. Feliksa Stasicy z 14.04.1988 r.

${ }^{25}$ „Wiadomości z prowincji św. Antoniego i bł. Jakuba Strzemię Ojców Franciszkanów w Polsce” (dalej: „Wiadomości z Prowincji”) R. 3: 1988, s. 4.

${ }^{26}$ „Wiadomości z Prowincji” R. 4: 1988, s. 19.

27 AKPK. Korespondencja bpa Luisa Bambaréna do prowincjała o. Feliksa Stasicy z 21.12. 1988 r. 
skiej w diecezji Chimbote. Był to trudny okres, ale bardzo pożyteczny. Poznali rzeczywistość miasta i wsi w górach. $Z$ powodu braku kapłanów od początku włączeni byli w pracę duszpasterska. W dniu 17 lipca do Pariacoto sprowadził się o. Jarosław, aby przygotować dom do zamieszkania. Ludzie zauważywszy misjonarza przychodzili do niego z prośbami, aby odprawiać Mszę św. w górach z okazji odpustów. W takiej sytuacji o. Jarosław nie miał czasu na przygotowanie domu, ale rozpoczął od zaraz pracę duszpasterską.

W taki sposób rozpoczęła się misyjna formacja ludu Bożego. Na początku sierpnia przybyli o. Zbigniew Strzałkowski i o. Michał Tomaszek, który przyjechał z Polski. Później udał się na kurs języka hiszpańskiego do Li$\mathrm{my}^{28}$. Dnia 30 sierpnia 1989 r. w uroczystość św. Róży z Limy, patronki Peru, nastąpiło oficjalne objęcie nowej placówki misyjnej Pariacoto ${ }^{29}$. Bardzo szybko ujawniły się nowe możliwości i potrzeby ludności andyjskiej, przede wszystkim konieczność misyjnej formacji oraz w jaki sposób i jakimi środkami ewangelizować campesinos.

Adhortacja apostolska Evangelii nuntiandi w punkcie 73 mówi: „potrzebne jest poważne przygotowanie dla tych wszystkich, którzy pracują w dziele ewangelizacji". Przypomniała o tym także Kongregacja Ewangelizowania Narodów ${ }^{30}$. Misjonarze sami musieli wiele wysiłku włożyć we własną formację i formować przede wszystkim katechistów, którzy w terenie mieli być odpowiedzialni za formację mieszkańców rejonu określonego jako misja Pariacoto ${ }^{31}$.

Adhortacja będąca zbiorem dyrektyw z Synodu Biskupów z 1974 r. była zaproszeniem do bycia dyspozycyjnym wobec apostolatu zgodnie $\mathrm{z}$ wymogami naszych czasów. Evangelii nuntiandi wprowadza umiejętność radzenia sobie w sytuacjach, w których znajduje się misjonarz. Tak też całkowicie dobrze zaczęli radzić sobie nowo przybyli franciszkanie. Wiadomość o tym, że przybyli rozeszła się szybko wśród ludności ponad $1000 \mathrm{~km}^{2}$ parafii andyjskiej. Zaczęli odwiedzać wioski - wspólnoty. Do większości nie było dojazdu samochodem, do dyspozycji pozostawał koń lub osioł. Do niektórych wiosek, aby pokonać odległość potrzeba było nawet 5 godzin jazdy na koniu. Zanim o. Jarosław Wysoczański został ustanowiony przełożonym tej wspólnoty ${ }^{32}$, wspólnie podjęli decyzję o przydzieleniu każdemu pewnych obowiązków.

O. Jarosław zajął się koordynowaniem pracy w parafii i życia wspólnoty, o. Zbigniew sprawami ekonomicznymi i programem socjalnym na terenie misji, a o. Michał uczył się języka hiszpańskiego w Limie. Zgodnie z wyma-

${ }^{28}$ AKPK. Korespondencja o. Zbigniewa Strzałkowskiego, o. Michała Tomaszka, o. Jarosława Wysoczańskiego do prowincjała o. Zdzisława Gogoli z dn. 3.10.1989 r.

${ }^{29}$ Objęcie placówki dokonało się w obecności bpa Luisa Bambarena, o. Stanisława Olbrychta delegata ze strony Prowincji, ks. Piotra Martineza, o. Michała, o. Zbigniewa i o. Jarosława. Ten historyczny akt rozpoczęto Mszą św. koncelebrowaną w Pariacoto.

${ }^{30}$ Comento sotto l'aspetto teologico, ascetico e pastorale, Roma $1976 \mathrm{r}$.

${ }^{31}$ J. E s q u e r d a - B i f e t, Spiritualià e animazione missionaria, Assisi 1977 (rozdział 2).

32 AKPK, Sygn.: N 539/89 Dokument nominacyjny o. Jarosława Wysoczańskiego na przełożonego domu zakonnego w Pariacoto, z dn. 30.12.1989 r. 
ganiem biskupa zorganizowali rady duszpasterskie i ekonomiczne w Pariacoto, Yautan, Cochabamba, Cachipampa, Pampas Grande.

Przygotowali w Pariacoto projekt szkolenia z katechizmu. Podzielili całą misje na trzy grupy. Wszystkie one przeszły podstawowy poziom nauki. O. Jarosław miał dwa kursy, o. Michał miał trzy. Bardzo wielu ludzi uczestniczyło w tych kursach, byli zadowoleni i frekwencja rosła. O. Zbigniew przygotowywał już następny cykl szkolenia. To też dawało poczucie wielkiej siły i mogło drażnić terrorystów.

Najwięcej doświadczenia zdobywali podczas wędrówek, odwiedzając rozrzucone po ogromnej parafii punkty misyjne. To wędrowanie po górach to poważne przedsięwzięcie. Oprócz dobrego prostego kazania, słów pociechy, udzielania sakramentów, potrzeba było zdrowia i wytrwałości. To była ciężka praca, w ciagu pół roku odwiedzili 70 wspólnot.

Czasami do Pariacoto przychodzili ludzie z oddalonych wiosek prosząc, by częściej odwiedzać ich miejscowość, gdyż raz w roku to zbyt mało. Prosili o odprawianie Mszy św., asystowanie przy ślubach czy udzielenie sakramentu chrztu świętego.

Kościelny związek małżeński często jest w tym kraju zawierany po wielu latach wspólnego życia na kontrakcie cywilnym, gdy rodzina jest już wielodzietna. Wiele dzieci i młodzieży żyje bez chrztu, bez pierwszej Komunii św. Tak się dzieje w parafiach, gdzie są kapłani, a co dopiero w górach, gdzie widzą księdza raz w roku.

Praca duszpasterska w oddalonych i wysoko położonych osiedlach koncentrowała się zwykle wokół świąt patronalnych - odpustów. Zbyt rzadkie odwiedziny misjonarzy dawały większe szanse różnym grupom sekciarskim, które były chętnie przyjmowane ze względów praktycznych - udzielali pomocy materialnej ${ }^{33}$.

Ojcowie mieli zwyczaj wyruszać popołudniem. Najpierw jechali samochodem, potem przesiadali się na konie, które specjalnie na nich czekały w umówionym miejscu. Czasami ostatni odcinek drogi trzeba było pokonać pieszo. Przyzwyczaili się już do gór, do odmiennych reakcji organizmu na dużych wysokościach, ale $\mathrm{w}$ pierwszym okresie przyśpieszone bicie serca i problemy $\mathrm{z}$ oddychaniem dawały się im odczuć. Owe dolegliwości były oczywiście zauważane przez tubylców, dlatego po przybyciu do wsi dawano im często do wypicia wywar ze specjalnych ziół. Do zwyczaju należał też poczęstunek gorącą strawą. Gotowano ją na zwyczajnym palenisku obłożonym kamieniami. Funkcje spiżarni na żywność stanowiły tace zawieszone na sznurkach, aby zakradające się nocą zwierzę niczego nie wyjadło. Wieczorne spotkania przy kolacji były dla misjonarzy nie tylko lekcjami keczua, ale i doskonała okazja, by poznać środowisko. Mieszkańcy bardzo chętnie opowiadali o swojej historii, o biedzie, o konfliktach, smutkach i radościach.

W czasie od grudnia do marca, a więc w okresie pory deszczowej, następowała przerwa w wyjazdach w góry. Wiązało się to $\mathrm{z}$ niebezpieczeństwem la-

${ }^{33}$ AKPK. List do Prowincjała o. Zdzisława Gogoli z dn. 3.10.1989 r. 
win błotnych, które w Andach są zjawiskiem normalnym i należy to uwzględnić w podejmowanej pracy duszpasterskiej.

Przyjazd do wsi misjonarzy był uroczysty. Stare kapliczki z okazji ich przyjazdu przyozdabiano kwiatami. Najpierw była nauka śpiewów i katecheza, potem Msza św. Misjonarze zauważyli, że tutaj, inaczej niż w wiejskich polskich kościołach, mężczyźni starali się być jak najbliżej ołtarza. Kobiety w odświętnych sukniach przychodziły do świątyni ze swoimi pociechami, czasami nawet karmily je podczas liturgii. Po Mszy św. radowano się ze wspólnie sprawowanej Eucharystii, to znaczy tańczono do samego rana. Atmosfera podsycana była kaliczie - alkoholem rozcieńczonym gorącą wodą i sokiem $\mathrm{z}$ cytryny. Thumaczono to zjawisko niska temperatura, a alkohol używany był aby chłód nie dokuczał zbyt mocno. Na drugi dzień, według ich relacji, najczęściej rano organizowali katechezę. Potem była Msza św., czasem chrzciny i rzecz dla wsi najważniejsza - wspólna procesja ku czci świętego, który jest patronem danej wspólnoty. Procesja była okazała, sypano kwiaty, palono kadzidło, grała orkiestra i wszyscy śpiewali swoje pieśni.

Po obiedzie misjonarze przeważnie opuszczali wieś, by dotrzeć o przyzwoitej porze do Pariacoto, a zabawa trwala dalej. Ludzie campesinos maja jakby dwie twarze. Pod pozorami prymitywizmu i zacofania ukrywają nieprzeciętną inteligencję i jasność umysłu. $O$. Zbigniew miał dar wynajdywania liderów w wiejskich wspólnotach, którzy później byli pomocni przy organizacji pracy duszpasterskiej ${ }^{34}$.

Szczególnie trudnym dla andyjskiego mieszkańca jest to, że by zostać chrześcijaninem, musi w pewnej mierze wyrzec się swojej kultury, swoich przodków, swojej rodziny. W najważniejszej domenie życia duchowego w swoim życiu religijnym będzie musiał wymawiać obce jego mentalności słowa, wykonywać gesty, które nie wyrażają dla niego nic albo niewiele. Posługiwać się znakami, które są sprzeczne niejednokrotnie z tradycjami jego narodu, społeczności, do której należy. Sprzeciw pogańskiego otoczenia wobec współbrata, który przyjął chrześcijaństwo, nie jest sprzeciwem wobec Jezusa, ale wobec agresji obcej kultury, która ma monopol na sposób wyznawania wiary w Jezusa Chrystusa. Przyjęcie chrześcijaństwa bywa traktowane czasem przez pogańskie środowisko jako wyrzeczenie się przez konwertytę własnej narodowości.

Misjonarze byli zadowoleni z tego, co już udało się im osiagnąć. Snuli bardzo śmiałe, dalekosiężne plany na miarę zapału, który im towarzyszył. O zagrożeniu ze strony terrorystów słyszało się od czasu tu i ówdzie, ale nikt nie traktował tego zbyt realnie, bo w ciagłym stresie, niepokoju i napięciu na pewno nie dałoby się pracować $\mathrm{z}$ takim zaangażowaniem. Mieli jeszcze niewielkie rozeznanie w sytuacji politycznej kraju i zaczęli patrzeć realnie na problem terroryzmu. Zauważyli, że życie ludzkie mało dla tubylców znaczyło, dla śmiesznie małych pieniędzy, człowiek potrafi zabić człowieka. Jak należy

${ }^{34}$ Z. G o g o la OFMConv, W Peruwiańskie Andy z Pokojem i Dobrem, Kraków 2001 s. $106-107$. 
zmienić świadomość tych ludzi, by zło, które potrafią czynić, budziło w nich poważne wyrzuty sumienia i to na tyle duże, by stawały się one barierą do dokonywania kolejnych złych czynów? Wybór metody pracy na misji w takim kraju jak Peru nie jest zupełnie prosty. Chociaż o terrorystach mówiono najczęściej „la peste”, czyli dżuma, to jednak z tymi właśnie terrorystami żyli na co dzień, pracowali, bawili się. O. Zbigniew opowiadał, że po praktyce odbytej u o. Pablo w Moro wyraźnie zobaczył, że krzewicielami komunizmu były tam głównie osoby, które studiowały kiedyś w Związu Radzieckim lub innych krajach socjalistycznych. Zastanawiali się też, jaki był naprawdę stosunek miejscowej ludności do nich. Byli białymi, a tutaj gringos lubi się i toleruje tylko wtedy, gdy mają pieniądze. Bywały również i takie sytuacje, o czym opowiadali inni misjonarze, że zaangażowanie i pobożność Peruwiańczyków były tylko pozorne $\mathrm{e}^{35}$.

Ojcowie wraz z siostrami zakonnymi, które w Pariacoto pracowały od 1971 roku zorganizowali duszpasterstwo młodzieżowe, które miało być pomocne w duszpasterstwie chorych, katechizacji na wioskach, organizacji liturgii, a także w działalności kulturalnej. Dla systematycznej katechizacji, a tym samym dla przezwyciężenia wpływów protestantów planowali założenie radia parafialnego w duchu św. o. Maksymiliana Kolbego. Pracowali nad zmianą mentalności „compesinos" którym uświadomili, że misjonarze nie są ,autoridades" - ktoś stojący nad nimi, ale są razem $\mathrm{z}$ nimi $^{36}$.

Dużym problemem jest pijaństwo. Ojcowie wymagali, aby w uroczystościach kościelnych, procesjach, nabożeństwach, uczestnicy nie byli pod wpływem alkoholu. Europejski porządek roku też jest tutaj zmieniony: na przykład w Poście trwa karnawal, w Adwencie można brać śluby. Wielożeństwo, choć może nie powszechne, nie jest tu czymś dziwnym. Kradzieże są rzeczą powszednią, a to, iż udało się okraść gringo, jest powodem do dumy. Zdarzyło się i tak, że o. Michał po odpuście w La Victoria - musiał wracać pieszo 4 godziny, gdyż właściciel konia po spożyciu alkoholu zmienił decyzję i nie użyczył konia. Trudno było pojąć wiele zachowań tubylców, między innymi i to, że umierają prawie z głodu i braku wody, ale gdy nadejdzie odpust, nadużywają piwa, które jest tak drogie, że nawet wiele bogatych osób w miastach nie korzysta z niego.

Misjonarze niejeden raz musieli naukę religii wśród dorosłych zaczynać od początku. Istnieją osiedla położone wysoko w Andach, z których ludzie bardzo rzadko schodza $w$ doliny. Wielu $\mathrm{z}$ nich nie wie, co to jest morze, jak wygląda ocean, chociaż to tylko kilkadziesiąt kilometrów od Pariacoto. Ich światem są góry i nie za bardzo wyobrażają sobie, że istnieje jeszcze coś poza nimi. Do takich przysiółków misjonarze ze względu na czas trafiają bardzo rzadko. Aby tam dotrzeć, trzeba zorganizować kilkudniową wyprawę. Jeśli więc mieszkańcy mówiący tylko w języku keczua spotkali się z kapłanem raz

${ }^{35}$ M. F rankows k a, Podstawy gospodarki wiejskiej w Peru w ostatnim okresie panowania Inków $i$ w pierwszym stuleciu po konkwiście, Poznań 1967 s. 161 i ns.

${ }^{36}$ AKPK. Korespondencja o. Zbigniewa Strzałkowskiego do prowincjała Zdzisława Gogoli z dn. 16.07.1989 r. 
do roku albo i rzadziej, a opowieści o ich miejscowych bóstwach, żyjących według ich wierzeń tam, w górach, obok nich, przekazywane są z dziadapradziada, to oczywiste, że owe miejscowe wierzenia będą bliższe ich sercu. Ale nawet wtedy, gdy zaczynać trzeba od podstaw, podczas ewangelizacji wyczuwa się w tych ludziach ogromne naturalne wyczucie Boga. Łatwo przychodzi im nauka i rozumienie dekalogu, ponieważ zgodny on jest ze stosowanym w tych społecznościach prawem naturalnym.

Oprócz pracy duszpasterskiej misjonarze podejmowali różne inicjatywy socjalne, aby pomóc ludności ${ }^{37}$. W 1989 roku Peru przeżywało wielką suszę, która dotknęła również i naszą misję. W górach brakowało wody do picia, gospodarstwa domowego i uprawy roślin. Ludzie spożyli wszystko co mieli, nawet nasiona na kolejne zasiewy. Pojawiły się choroby. W obliczu takich klęsk Episkopat peruwiański podjął ścisłą współprace z rządem. Chodziło o dotarcie z pomocą do miejsc najbardziej zagrożonych. Poprzez Kościół przekazywane były transporty żywności, docierające $\mathrm{z}$ różnych stron świata, od różnych organizacji. Przesyłane były również pieniądze, które rozdawało się poszczególnym parafiom jako wsparcie w obliczu klęski. W parafiach tworzyły się specjalne komitety, które pośredniczyły w przyjmowaniu darów i zajmowały się ich rozdziałem. Kościół pragnął, aby owa pomoc nie była dostarczana za darmo, ale by wykorzystać ów moment i nakłonić opornych w tym względzie Peruwiańczyków do pracy na rzecz własnego środowiska, własnej osady, własnego osiedla. W zamian za żywność i pieniądze tubylcy naprawiali drogi, budowali domy i kanały doprowadzające wodę.

W naszej franciszkańskiej misji było wiele takich projektów. $Z$ jednej strony było to dobre, a $\mathrm{z}$ drugiej - zastanawiali się, czy zbyt rozbudowany program gospodarczy nie niesie pewnego niebezpieczeństwa: byli przecież przede wszystkim kapłanami, a nie gospodarzami. Czy więc przez zbytnie zaangażowanie w taką właśnie działalność nie stracą swej franciszkańskiej tożsamości? Dlatego zależało im na tworzeniu grup świeckich, które by się tymi sprawami zajmowały szczegółowo. W Pariacoto grupa ludzi świeckich uformowała komitet pomocy Caritas. Na czele komitetu stał człowiek świecki. On sam prowadził rozdzielanie żywności i podlegał bezpośrednio władzy Caritasu w Chimbote.

Misjonarze postanowili zmierzyć się dodatkowo $\mathrm{z}$ innym zagrożeniem. Była nim choroba - cholera. Gdy zaatakuje ona górskie wioski, epidemia jest nie do opanowania. Historia wiele razy dawała temu świadectwo. Sprowadzono pielęgniarki i lekarzy, którzy wygłosili pogadanki na temat: czym jest cholera, jak można się nią zarazić, jak się rozprzestrzenia, jak można jej zapobiec. Na każdym kroku przypominano o tym, by zachowywać czystość, szczególnie o konieczności częstego mycia rąk. Praca franciszkanów w tym rejonie mogła być oceniana pozytywnie, przyniosła widoczne efekty zewnętrzne, co było przeciwne ideologii Sendero Luminoso i dlatego terroryści postanowili ich zniszczyć.

${ }^{37}$ Relacje ustna o. Zbigniewa Strzałkowskiego z $1990 \mathrm{r}$. 
Pierwsze wydarzenie, które dało im wiele do myślenia, miało miejsce w lutym 1990 roku. Był to atak terrorystów. Już nieco wcześniej franciszkanie zaczęli odczuwać wokół siebie dziwną atmosferę. Ktoś próbował robić wywiady środowiskowe. Przy okazji imprez sportowych lub sprzedaży żywności odbywały się tajemnicze spotkania. W czasie wakacji przyjeżdżały i wyjeżdżały grupy młodzieży, rodziny odwiedzały się nawzajem - wszystko wydawało się być czymś normalnym, a jednak czuło się dziwne, nieco inne zachowania ludzi.

Przeczucia okazały się prawdziwe. W nocy z 16 na 17 lutego terroryści zaatakowali Pariacoto wkroczyli w liczbie około czterdziestu, dobrze uzbrojeni; podłożyli bomby i przez ponad godzinę strzelali z karabinów. Poszukiwali alcalde Pariacoto i osób zaangażowanych politycznie. Wysadzili w powietrze centralę telefoniczną oraz posterunek policji. W drodze do Huaraz zabili dwóch inżynierów. Ludności cywilnej nie atakowali, podobnie kościoła ani domu sióstr Esclavas.

Nawoływali mieszkańców, aby ci wyszli na rynek i manifestowali obecność Sendero Luminoso. Szukali także policjantów, którym udało się przed nimi schronić. Nikt nie stawiał oporu. Po tym ataku pozostał strach, kilkoro dzieci zawieziono do szpitala w Casma. Odtąd wieczorami ludzie nie wychodzili z domów ani nie używali w mieszkaniach lamp naftowych ${ }^{38}$. Terrorystom chodziło o rozprawienie się $\mathrm{z}$ władzami wioski lub o zwykłą próbę, o sprawdzenie, jak wieś zachowa się wobec ich ataku, jakie będą reakcje mieszkańców. Po akcji terroryści przez podstawionych ludzi wypytywali mieszkańców o to, co się wydarzyło. Pariacoto zostało całkowicie opuszczone przez władze, policjanci już nie wrócili (było ich 9), alcalde zmienił miejsce zamieszkania, a nowego nie wybrano, ponieważ stałby się przynętą dla terrorystów. Jedynym autorytetem stali się misjonarze i siostry zakonne, które pracowały tam od 1971 roku.

\section{MĘCZEŃSTWO O. ZBIGNIEWA STRZAŁKOWSKIEGO I O. MICHALA TOMASZKA}

Dnia 9 sierpnia 1991 roku o. Zbigniew i o. Michał zostali zamordowani przez Sendero Luminoso. Naocznymi świadkami uprowadzenia misjonarzy były siostry zakonne ze Zgromadzenia Esclavas del Sagrado Corazón, Berta i Lucila.

\section{Opis zbrodni wedlug relacji siostry Berty Hernandez Guerra}

„Dnia 9 sierpnia 1991 roku w piątek o godzinie $18^{45}$ o. Michał Tomaszek i dziewięciu młodych animatorów z Katechezy Rodzin a także s. Maria Elena powrócili z Huaraz. Następnie rozpoczęła się wieczorna Msza Święta. Weszłam do zakrystii aby powiedzieć o. Michałowi, że przybyli «cumpas» to znaczy terroryści. Ale on nie uwierzył i razem ze Zbigniewem wrócili do ołta-

${ }^{38}$ AKPK. List o. Jarosława Wysoczańskiego do prowincjała z dnia 20.02.1990 r. 
rza by zakończyć adorację Najświętszego Sakramentu. Podczas Mszy świętej Michał patrzył w górę i dotykał rękami głowy. Zbigniew z rozszerzonymi oczami patrzył w stronę drzwi. Po mszy zadecydowali, że piątkowe spotkanie z młodzieżą odbędzie się normalnie. Gdy byłam na terenie wewnętrznego ogrodu usłyszałam mocne uderzenia w drzwi i zobaczyłam światła latarki. Siostra Lucila otworzyła drzwi. Wszedł człowiek który miał na głowę naciągniętą czapkę zasłaniającą całą twarz, z wyciętymi otworami na oczy. Był uzbrojony. Lusy powiedziała, że rozkazuja by zawołano ojców. Wyszedł o. Zbigniew. Terrorysta zapytał:

- Ilu was jest?

- Pięciu - padła odpowiedź.

- Gdzie jest reszta? Niech przyjdzie reszta!

Wyszedł o. Michał. Oni znowu pytali, gdzie jest reszta. Niech wyjdzie reszta! Michał i Zbigniew odpowiedzieli, że reszta to postulanci. Kapłanami są tylko oni dwaj. To nie zadowoliło terrorystów. Znów krzyczeli:

- Gdzie jest reszta? Niech wychodzą!

Zbyszek powiedział zdecydowanym głosem:

- Weźcie mnie, ale ich zostawcie.

Terrorysta dał rozkaz by zabrać Michała i Zbigniewa. Potem zażądali kluczy. Samochodami odjechali wraz z Michałem i Zbigniewem pod dom wójta. Udało mi się wsiąść do auta razem z ojcami. Michał odwrócił się i powiedział coś do Zbyszka w języku polskim. Nie zrozumialam, ale brzmiało to jakby „przyszedł już czas”. Potem trzech terrorystów weszło do samochodu w którym znajdowała się nasza trójka. Włączyli silnik. Ujechaliśmy trochę $\mathrm{i}$ jeden $\mathrm{z}$ terrorystów powiedział:

- Niech ta kobieta wysiądzie.

- Muszę wiedzieć dokąd ich zabieracie.

Wtedy o. Zbigniew powiedział:

- Berta wysiądź.

Upadłam na ziemię. Strzelano w moim kierunku. Odskoczyłam pod mur. Nie chciałam stracić z oczu samochodu ani reszty terrorystów, którzy biegli za autem. Zniknęli w ciemności nocy.

Wróciłam do domu parafialnego gdzie zastałam grupę kilkunastu osób. Około godziny 21 usłyszano w okolicy Pueblo Viejo strzały. Potem przyniesiono nam straszną wiadomość. W okolicy Pueblo Viejo widziano trzech zabitych: dwu ojców Zbigniewa i Michała oraz Domingo Padilla Chacpi - wójta Pariacoto"39.

\section{Relacja przekazana przez siostrę Lucilę Reinozo}

„Około godziny 5 rano pojechaliśmy autem by przywieźć ciała. Po przyjeździe do Pueblo Viejo znaleźliśmy zwłoki ojców niedaleko dawnego kościoła. Z ich ciał wypłynęło dużo krwi. Ziemia była mokra i czerwona. Na ple-

${ }^{39}$ Relacja s. Berty Hernández Guerra, Pariacoto 11 września 1991 r. Przetłumaczył z języka hiszpańskiego o. Jarosław Wysoczański. 
cach martwego o. Zbigniewa znajdowała się kartka z napisem: «Tak umierają sługusy imperializmu». Potem przyjechała policja z Chimbote i ciała misjonarzy zawié́liśmy do kościoła w Pariacoto ${ }^{40}$.

Episkopat peruwiański uznał śmierć misjonarzy ojców Zbigniewa Strzałkowskiego i Michała Tomaszka za śmierć męczeńska. Na podstawie tego mógł być podjęty proces przygotowawczy do beatyfikacji, do ogłoszenia ich błogosławionymi. Na poziomie diecezjalnym proces ten został zakończony.

Mimo tragicznych wydarzeń, franciszkańska misja w Pariacoto nie została zamknięta. Dzieło zamordowanych podjęli następni współbracia, którzy głoszą wiarę i walczą o godne życie spychanych coraz bardziej na margines Indian $^{41}$.

${ }^{40}$ Relacja s. Lucila Reinoso, Pariacoto 11 wrzesnia 1991 r. Przethumaczył z języka hiszpańskiego o. Szymon Chapiński.

bote $\quad$ Oprócz Pariacoto franciszkanie pracują w dwóch innych miejscach: w Limie i Chim- 